\title{
Diagnosis and proposals for tables adapted to wheelchair users: a case study on usability in a childhood and teenage care institution
}

\author{
Juliana Maria Moreira Soares, Andrea Regina Martins Fontes, Cleyton Fernandes Ferrarini, Miguel Ángel Aires Borrás \\ Universidade Federal de São Carlos \\ e-mails. julianammsoares@gmail.com; andreaf@dep.ufscar.br; cleyton@ufscar.br; maborras@ufscar.br
}

\begin{abstract}
This article aims to evaluate a table design adaptable for wheelchair users. This type of furniture is needed in educational spaces, rehabilitation institutes and even in homes, to perform various tasks. We used the case study approach, in which the assessed usage scenarios were located in an institution that offers treatment for children and adolescents with multiple kinds of disabilities, located in a medium-sized Brazilian city. A number of constraints for users and professionals were found, especially in regard to the adjustment of moving parts, appearance and the structure general instability. The assays resulted in alternative suggestions to improve the product, given the diversity of purposes by their users. Also, the need for the product's users participation (and other role players also present on this interaction) in the development process was evidenced.
\end{abstract}

Keywords: adapted furniture, assistive technology, usability, ergonomics, product development.

\section{Introduction}

The use of an object brings to the user important perceptions of its usability and dynamic operation, ease or difficulty of use, such as notions of leeway. It is through the object that the user performs their actions and strategies to achieve their goals. Thus, a user is one of the most important knowledge sources regarding a product, being a potential innovation source (GAITHER; FRAZIER, 2002; VON HIPPEL, 2005), revealing the importance of consumer feedback and participation in the process of developing a new product.

This idea is essential for the development product focused in Assistive Technology, in which we are discussing great sizes and complexities of anthropometric difference (and multiple and distinct needs), inseparable from the notion of a product design that should communicate and meet such specificities (NEWELL; GREGOR, 2000; BENEDETTO, 2011). Considering the situations expressed above, this article aims to analyse a piece of furniture, described as an adjustable table of height and the angle of its top it is, flexible and adaptable for wheelchair users. This piece of furniture is known in the Brazilian market as an "adapted school table".

This study was performed in the context of its use inside a care institution located in a medium-sized Brazilian city, for children and adolescents with multiple kinds of disabilities. The institution promotes activities for children and adolescents (between one and sixteen years of age), offering different types of therapeutic care with a multidisciplinary team, specialized pedagogical supervision, social and nursing care, and also an abundance of Assistive Technology resources. Beyond this, the institution has daily meal services, transportation, diapers, medication and promotes a specific diet for assisted gastrostomy (feeding tubes) and gastrointestinal disorders.

The issue of Assistive Technology (AT) can be understood, among many other concepts, as:

Every tool, resource or process used in order to provide greater independence and autonomy for people with disabilities (GALVÃO FILHO; GARCIA, 2012, p. 01).

According to Cook and Hussey (2002), the AT is a way to reduce the disabling interference commonly caused by many environments for people with disabilities and can include a wide range of apparatuses and services. It is worth remembering that the world has more than one billion people living with some kind of disability, according to the World Report on Disability, made in 2011 by the World Health Organization (WHO) and World Bank (WORLD HEALTH ORGANIZATION, 2011).

Also, recent studies warn about this situation, stating that "the studies and analyses of the research processes and development in the area of assistive technology are still lacking" (GALVÃO FILHO; GARCIA, 2012, p. 08). Now that the debates related to the social inclusion of such population parcels are increasingly occurring critical 
discussions in society, the issue of assistive technology comes as a significant point to be reinforced ${ }^{1}$, understood and researched as a mechanism in support of this situation, corroborating the idea of social integration for these groups, precariously included in the fields of health, education, work and social rights (BARTALOTTI, 2006).

It is relevant to note that the discussion about the ATs effectiveness is an internationally increasing debate, being found in studies outside of Brazilian territory, analysing correlated issues (PHILLIPS; ZHAO, 1993; MANN, 1999; WESSELS et al., 2003).

The table evaluated in this study is widely used by the institution in several of their activities. The focus of the study was to observe the object in use in various situations (by the users and the professionals). This article presents a brief review about usability, aesthetics and the emotional aspects of design, aiming to base the analysis of the selected desk on the interaction between the user and the object. Then, the description of the research method, the information sources and procedures performed by the authors are introduced. After presenting the results, this paper shows the analysis and the final remarks of the article.

\section{Usability and related dimensions}

Usability does not exist in any absolute sense; it can only be defined with reference to particular contexts. This, in turn, means that there are no absolute measures of usability, since, if the usability of an artefact is defined by the context in which that artefact is used, measures of usability must necessarily be defined by the context too (BROOKE, 1996, p. 01).

Many of the concepts related to usability today are still embedded within the informatics, computer systems and software contexts - as a probable and hypothetical reminder about the ambient of the concept emergence, between 1970 and 1980, when the first accessible computers began to be used in companies and smaller offices. Therefore, the word usability was used to emphasize the concept from the functional perspective and utilitarian aspects of these systems (JORDAN, 1998).

In the process of time, the term usability gained strength in broad spectrums, expanding this notion out of computing environments, and also going beyond a level of comprehension only connected to utility and effectiveness, turning into one of the central issues in the

\footnotetext{
${ }^{1}$ Although the concept and the problematics related to inclusion are complex and difficult to define in few lines - intrinsics to the situation of exclusion, which also "is complex and multifaceted process, a configuration of material dimensions political, relational and subjective" (SAWAIA, 1999, p. 09) - it consists on a topic that should be discussed in all possible spheres, being of paramount importance associate the autonomy and the possibility of independence generated for handicapped population through assistive technologies, to this process of inclusion.
}

creation of many products (JORDAN, 1998). Not only governed by functionality, today usability is used as a term that encompasses many facets of a product, such as user's attitudinal questions, regarding the use and combination of colors, subjective satisfaction, study and focus on the user, among other more subjective aspects (FOLEY et al., 1997; KULPA et al., 2010; MARCUS, 1982; NORMAN, 1986). The ease of use of many of its aspects (NIELSEN, 1993) is one of the points belonging to the usability concept that is most interesting to the table handling issue chosen for this study.

The importance of this idea is linked to the fact that it is supposed that a table for this purpose - which has high flexibility to meet the assumption of its requirement - has a friendly and intuitive usage interface, intending to be easily operated by the wheelchair users themselves, or by their companions. As a useful idea to this captation of essential product characteristics, and in an analogy of Brooke's theory (BROOKE, 1996) previously discussed, it is the adoption of a user-centered design concept in the product development process, with the understanding that in this case the users are multiple - being made up of not only the wheelchair user, but by all the actors involved in the use of the table (professionals which perform treatments and other activities as also by caregivers, and family members).

This approach aims to visualize the interaction between the object and its users, allowing for a better understanding of this process by the project developers in different stages of this cycle, in order to perceive important aspects felt by the users of the given product, and capturing the impressions and collaborations directly from this dynamic. This idea can be summarized as follows:

The principle of user-centered design: If an object, a system or an environment is intended for human use, then its design should be based upon the physical and mental characteristics of its human users (insomuch as these may be determined by the investigative methods of the empirical sciences) (PHEASANT, 1997, p. 05).

Still, considering ergonomics as a concept which integrates various knowledge areas in order to facilitate the tasks, systems, products and environments for physical and mental abilities and people's limitations (KARWOSKI, 1996), the usability consists of one of the ergonomic requisites demanded for the success of the activity to be performed.

Regarding ergonomics, Dejours (2004) defines work as filling the space between the prescribed and effective, including technical and tacit knowledge, and leeway. This point is relevant to the usability of the table under study, since to achieve the objectives when using this object, the users, in the context of the childcare institution, tend to use 
various informal techniques to circumvent the difficulties found with its use, to be reported after.

\section{Aesthetic and subjective aspects}

Emotions are intrinsic to the dimension of the cognitive process, linked to the relationship with day-to-day objects (NORMAN, 2008), being fundamentally important to consider this aspect when designing a product, paying attention to its good acceptance and proportioning wellbeing within these terms, about its future use. Now that nicer and more attractive products have the tendency of causing this good effect (albeit in an implied way) on the users (NORMAN, 2008), the consideration of the subjective and affective dimension of a product within its development process strengthens, and this aspect has been increasingly studied by researchers from various areas (cognition, semiotics, design, and related), as well as applied by industry.

On the issue of Assistive Technology furniture, an idea often takes over the product design in this area, which is linked to highly stigmatized, medical looking and mechanical aspects, as is pointed out by authors (DESMET; DIJKHUIS, 2003; BISPO; BRANCO, 2008; PULLIN, 2009). Tubular structures and polymer covers with cold colors are very common, constituting characteristics with little potential for an affectionate relationship with users for use in many different niches, such a consumer from the child audience, or a person who intends to furnish his office to work with an adapted table.

The product patterns focused on a population with disabilities, then, requires a shift from the medical model of disability to the social model, considering the human being as a citizen who carries a self assigned identity, along with personal and social values in many complex spheres, including the objects arranged in their surroundings (PALACIOS, 2008; PULLIN, 2009). This kind of work seeks to analyze the aesthetic as an attribute that is able to create symbolic values between users and products, creating a pleasantness with its presence and use. The possibilities of exploration in the visual and psychomotor needs of the child are still powerful, when working, for example, with the colors and textures of the products related to the educational environment (MAFRA, 2008; SANTOS, 2012; VYGOTSKI, 1991).

Still in this scope, it is pertinent to bring a definition from the IEA (International Ergonomics Association), regarding the functions of the ergonomist in this process. Achieving a positive result coming from the junction of design applications and ergonomics within a system, bringing to the user a product that is friendly (presenting great usability), and at the same time, attractive (nicely achieving the subjective and objective dimensions), are some of the positive impacts that this collaborative work can bring.

Practitioners of ergonomics and ergonomists contribute to the design and evaluation of tasks, jobs, products, environments and systems in order to make them compatible with the needs, abilities and limitations of people (INTERNATIONAL ERGONOMICS ASSOCIATION, 2014).

It is still worth mentioning the existence of tests that aim to measure such subjective and emotional aspects, such as SUS and SD (LANUTTI et al., 2013). The SUS is a quick test devised by John Brooke in 1986, which promotes the users subjective evaluation after the interaction with the product, providing the test's participant the possibility of answer with either a positive or negative option, using the features exposed in a table. Yet, the SD is an evaluative method created by the researcher and psychologist Charles Osgood, in 1957, with the intention of assessing the user's sentiment in regards to various aspects of the product: brand, environment and physical properties among other features, by writing about antagonistic feelings related to the object in question. However, the application of such tests was not part of the research scope.

\section{Methodology}

The methodology of this study is characterized as qualitative, with the proposal of a single case study of the "adapted school table" in an analysis in loco, within an institution for adolescents and children with multiple disabilities. According to Creswell (2003) and Stake (1995), the strategy of using case studies for qualitative studies is pertinent, because it is possible to gather a more detailed variety of information through multiple methods of data collection.

For structuring this qualitative approach of the case study, the chosen techniques to approach the topic were spontaneous observations, open interviews, questionnaires and a brief analysis of the physical structure (GIL, 2002). The methodological procedures can be understood in Table 1.

As shown in Table 1, use of the internet as a research tool was taken advantage of, looking for the existence of similar models, in databases such as the National Catalogue of Assistive Technology Products (BRASIL, 2013) and the AbleData (2015) (an American database) with the intention of recognizing the main features of the current models available for sale in Brazil.

Perceptual analysis of the physical structure of the chosen model for this study was performed. This analysis surveyed the tangible characteristics of the object, but also its repercussions while performing different activities. Morphologic and located analyses in use allowed for an 
Table 1. Methodological procedures adopted for this research.

\begin{tabular}{|l|l|}
\hline \multicolumn{1}{|c|}{ Stage } & \multicolumn{1}{|c|}{ Procedure } \\
\hline i. Theoretical review & $\begin{array}{l}\text { Review of the issues that the subject of this study was based (AT, usability, aesthetic and } \\
\text { emotional product aspects). }\end{array}$ \\
\hline ii. Analysis of similar models & Internet-based research about available models In the Brazilian market. \\
\hline iii. Analysis of the physical structure & $\begin{array}{l}\text { Perceptual analysis of the furniture's physical characteristics, visual perceptions and user } \\
\text { interactions }\end{array}$ \\
\hline iv. Participant selection & Mapping of therapists and direct users of the table within the institution. \\
\hline v. Interaction with participants & $\begin{array}{l}\text { Open interviews, perceptions of use, characterization of the context/activities. The Terms } \\
\text { of Free and Informed Consent (TCLE) was distributed to the participants. }\end{array}$ \\
\hline vi. Hypothesis elaboration & $\begin{array}{l}\text { From the analysis of the interaction with the participants, hypotheses were elaborated to be } \\
\text { further investigated in the survey, through a questionnaire made in a semi-structured form. }\end{array}$ \\
\hline vii. Questionnaire application & $\begin{array}{l}\text { Application of semi-structured questionnaire to all professionals that use the table } \\
\text { (12 professionals). }\end{array}$ \\
\hline viii. Results analysis & Analysis of the findings made by the study, under the bibliographic referential. \\
\hline
\end{tabular}

Source: elaborated by the authors.

overview about where and how the use of the product within the environment of the institution occurred, permitting the evaluation of the main characteristics of the table, and its favourable and unfavourable points. Then, the table characteristics were evaluated in an applied form, in usage situations.

The professionals within the institution who have or had already had contact with this product were mapped. These professionals perform rehabilitation and educational activities with the institution's patients, such as speech therapy exercises and artistic activities. From this preliminary process, 12 professionals were located and interviewed, among speech and occupational therapists, physiotherapists and monitors (all female), reporting on the various contexts of such furniture's usage.

At first, there was an informal gathering of perceptions about the product, based on the spontaneous testimonials of those professionals. The professional respondents reported the demanding needs of users in therapy in relation to the table. It is emphasized that, due to the fact that many of the children treated are not able to speak, the testimony gathering was restricted to professionals who make use of the table in a very close way, being responsible for reporting situations of complexity linked to the use of the product and the final user (and also relatives, who occasionally attend the institution).

Based on the previous steps and from the interaction with the participants, the hypotheses could be developed, and it formed the basis of the questionnaires. A meeting was held with the institution's professionals to present the research and communicate about the semi-structured questionnaire's application.

The semi-structured questionnaires were applied containing closed questions with options, and open questions which allowed for free opinions. Some questionnaires were applied by the researcher with the aid of a collaborator, but others were handed over to professionals to be completed at a convenient time. A total of 12 questionnaires were completed. Before, during and after the application of this, small interviews took place with the first participants, covering topics of interest to the subject, which appeared by way of questions, and were also derived from the observation process. It is important to highlight that these first applications in loco were made as a pilot questionnaire, with the intention of checking the intelligibility of the document and the research.

The verbalizations were recorded on a digital recorder, generating a total of 4 hours of recordings. About 30 hours were intended for observations, studies about the table operation system and free verbalizations. Also, a total of 40 JPEG archives were generated by way of a semi-professional camera during the process. The analysis was taken from the responses to the questionnaires, previous steps and from the theoretical basis. This research was submitted to the Research Ethics Committee (Comitê de Ética e Pesquisa - CEP), belonging of the brazilian base named Plataforma Brasil, and it was approved under the report number 966575.

Also, an essential point to make is that this study's focus was the observation of the object in a usage situation, by the user and the therapists. This research could be complemented with the prospect of the manufacturer, designer, etc. in future works, but it was not within the scope of this case study.

\subsection{Characterization of the case study}

Therefore, the "adapted school table" studied here, fits as an Assistive Technology, from the moment that it allows the full use of this type of furniture by the wheelchair user, adjusting to the height that best suits him/herself (between 27,16 inches and 39,37 inches in height), and also choosing the angle of the top (between 0 and 90 degrees), taking into account the activity to be performed. In Figures 1 and 2, the main characteristics of the table can be observed. 
This table still meets the parameters of the 9050 standard from the Associação Brasileira de Normas Técnicas (ABNT) (ABNT, 9050:2004), an institution responsible for technical standardization in Brazil. In accordance with this

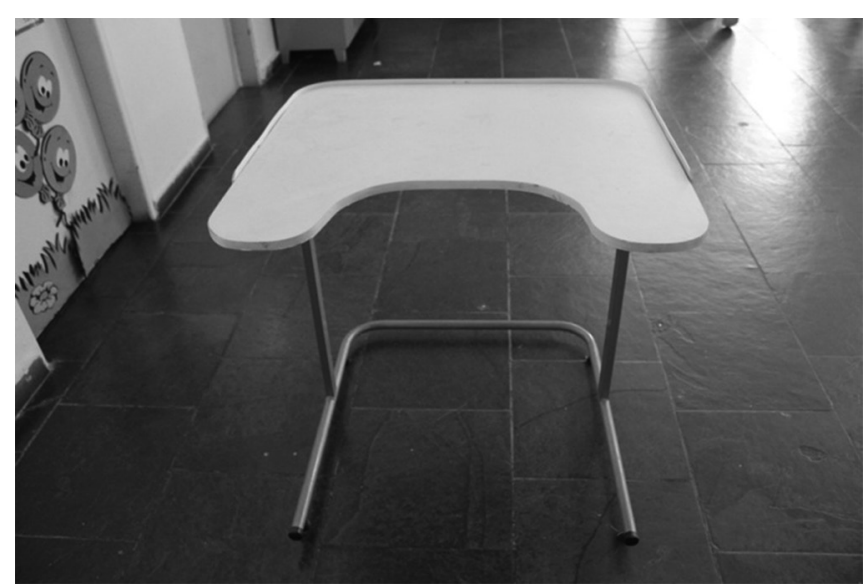

Figure 1. The "adapted school table". Source: elaborated by the authors.

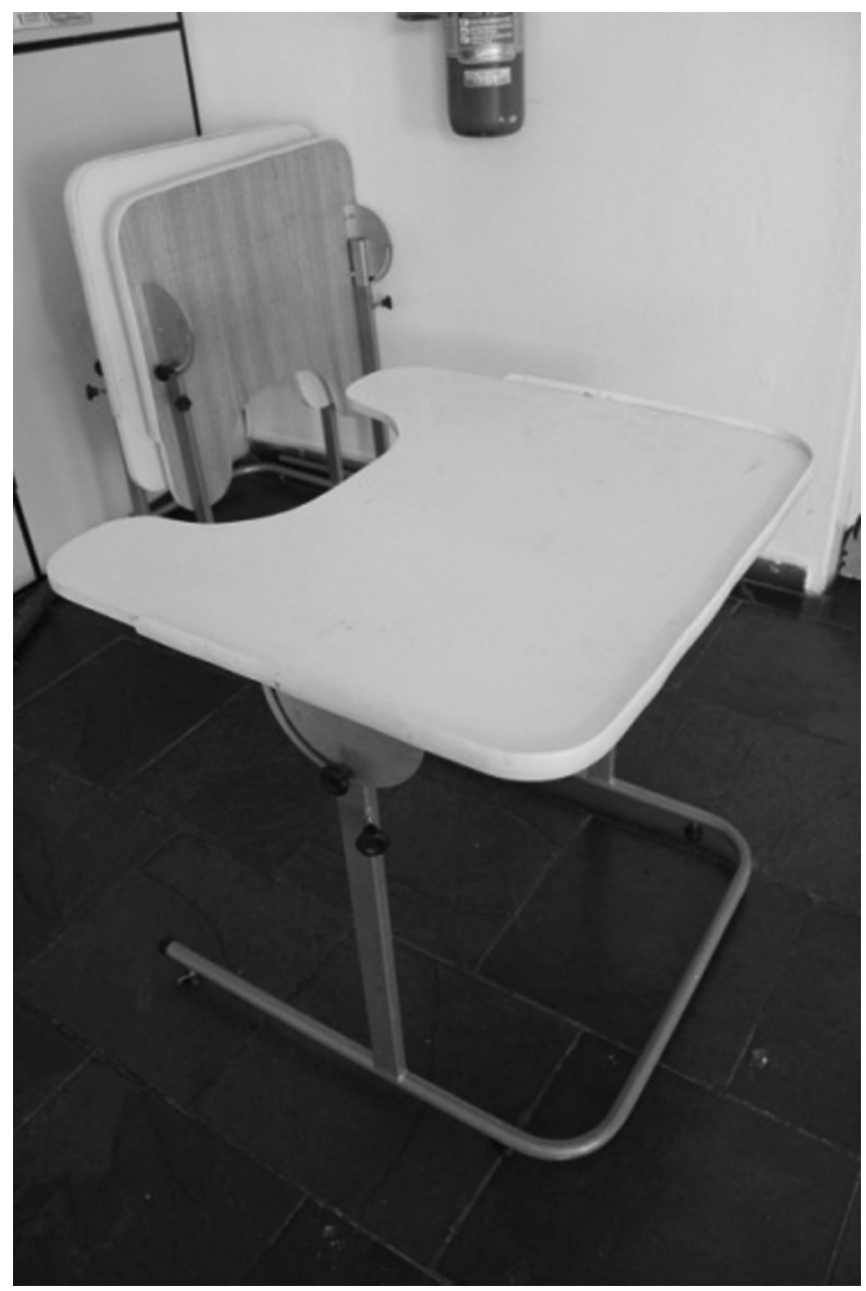

Figure 2. The "adapted school table" from another angle. Source: elaborated by the authors. standard, created in 2004, which deals with accessibility in buildings, furniture, spaces and urban equipment, "the tables or surfaces shall have a lowest free height of at least 28,68 inches from the floor" (ABNT, 9050:2004)2. However, these regulations do not drive any clause regarding the degree of the tabletop articulation, though this adjustment is very important to the performance of certain tasks (e.g. painting and reading).

Also, it is important to emphasize the relevance of this large degree of adjustability, since there is a wide anthropometric variety from person to person - therefore, a multitude of models of these products, with the presence of different dimensions between them (a factor that complicates and makes the interaction between the wheelchair and a common table uncomfortable with a fixed height - between 28,34 inches and 29,52 inches in the case of a table work).

The current production chain of AT products in Brazil includes 205 companies, 117 distributors, 160 manufacturers and 10 importers, who work with this kind of product line in at least one of their business niche ${ }^{3}$. Though seemingly expressive, the reality in AT in a country such as Brazil which has a population of approximately $23.9 \%$ of citizens with some sort of disability (about 45.6 million people) ${ }^{4}-$ demands attention and growth, with special regards to the offer and affordable values of these products.

\section{Results and discussion}

Initially, a series of hypotheses was constructed from the initial research procedures (described until step V, in Table 1). The questioning regarding the unsatisfactory usability of the studied furniture, according to the observations, possibly related to a development process distanced from their products' end users, as well as a lack of concern tangent to the subjective aspects of their design, were localized points with a larger overhang.

Still, it could be seen for what activities a table, adjustable in angle and height is essential and irreplaceable: for children engaging in food based, educational, artistic, educational, and speech therapy activities, this type of table is indispensable. Especially in such activities could not be carried out with a table without these kinds of adjustments, because the wheelchairs would not have space to fit under

\footnotetext{
${ }^{2}$ Parameters set according to ABNT NBR 13966 (ASSOCIAÇÃO BRASILEIRA DE NORMAS TÉCNICAS, 2008), entitled "Móveis para escritório - Mesas - Classificação e características físicas dimensionais e requisitos e métodos de ensaio" (in english: "Office furniture - Tables Classification and dimensional requirements and physical characteristics and test methods").

3 Data available on the National Product Catalogue for Assistive Technology website, organized by the Ministério da Ciência, Tecnologia e Inovação MCTI (BRASIL, 2013).

${ }^{4}$ According to data collected in the national census of 2010 , conducted by Instituto Brasileiro de Geografia e Estatística (IBGE, 2012).
} 
a common table (with a fixed height). Also note that this model features a great range of characteristics, noting that few models found for sale have all of the features presented in this table.

After the application of the questionnaires, it was noted that most of the participants stressed this essential character of the furniture's use within the institution's activities. However, despite the observed essentialness of this product for performing many routine tasks, as well as the requirement for the sensitivity and usability of its mechanisms (due to multiplicity of the anthropometric characteristics of its users, but also their monitors or caregivers, whom may vary in age, and consequently in muscle tone), it was possible to find many problems regarding the adjustability, making its use difficult at some stages of use, which is reported below.

In the beginning of this height adjustment, the four small rubberized supports (feet) which are responsible for the table's firm contact with the ground can be adjusted between 0,78 inches and 1,57 inches in height (see Figure 3). This mechanism is sensitive and small, probably to be used like an adjustment in regard to irregularities of the floor.

This adjustment is easy to make, since its thread mechanism easily allows the rubberized supports to remain at different heights when compared to each other, because there are no marks on the feet to properly point out the height level. According to the testimonials, some professionals did not even know that this adjustment option existed, because it is a very discreet mechanism: "Never knew this existed..." Also, it is too low, almost hidden and difficult to notice. The institution's professionals who had knowledge of this adjustment reported that prefer not to touch this part, since it can easily cause an unevenness on the table. Ergonomic reasons can also deter people from touching this adjustment, because it is demands squatting and/or bending of the back to move these supports and also the lifting of the table with one arm (which is fairly heavy, weighing about $22 \mathrm{lbs}$ ). Although the situation of adjusting by a wheelchair user was not witnessed, such a mechanism appears to be of little accessibility for this kind of user to perform this process in any simple way.

For height adjustment, two people are required for this activity to be finished more quickly, with one person on each table leg. A synchronicity should exist between these two people to reach to the same height on both legs, as there are no markings that identify the heights: We adjust by the eye, says one of the monitors. A homemade mechanism to check if the heights are equal can also be applied, which consists in putting some lightweight object, and observe their movement on the table.

Often, the task is also performed by one person (as in the case of the speech therapist, who individually attends their patients), coming to take almost twice as long than when held with two people. The clamping knobs (see Figure 4) are used to fasten the height (one on each table leg) - the metal structures (rectangular steel pipe) fit into, entering the upper structure (internal) inside the lower (external); the adjustment, when made, compresses the internal rectangular structure, setting the table at the desired height. This mechanism constitutes a barely effective fixation process, since abrupt falls in height on one side (or even both) during the use of the table have been reported with an average weight on the top, such as books and school coloring magazines. Such adjustments may also shorten the product life, since threading done with too much force can deform the rectangular steel. The process of adjusting the top also has the lack of reference point's problem, but is more easily controlled than the other adjustments previously mentioned.

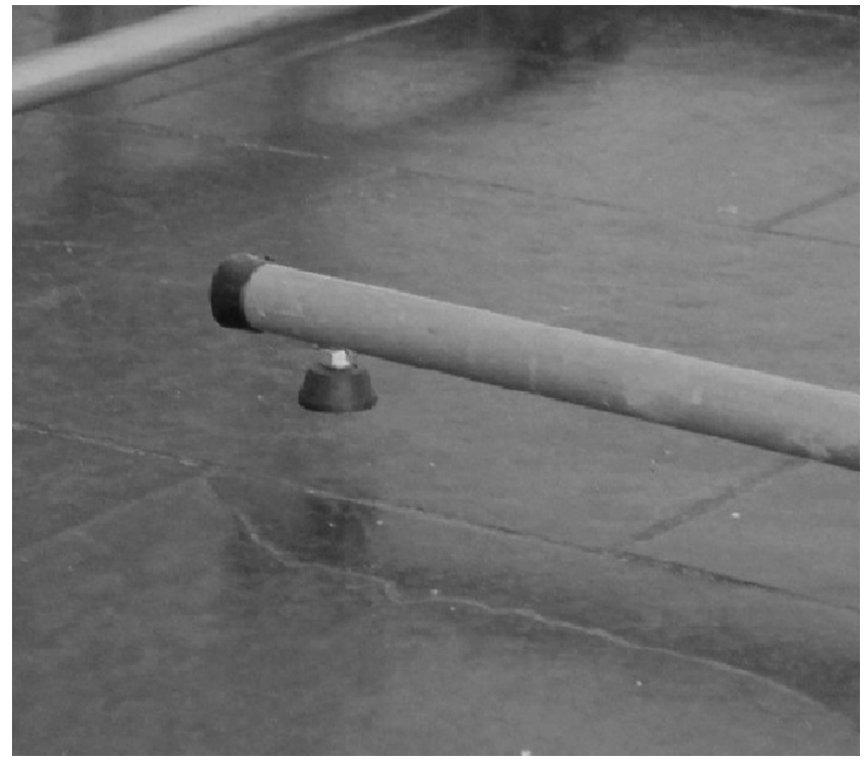

Figure 3. The small rubberized supports. Source: elaborated by the authors.

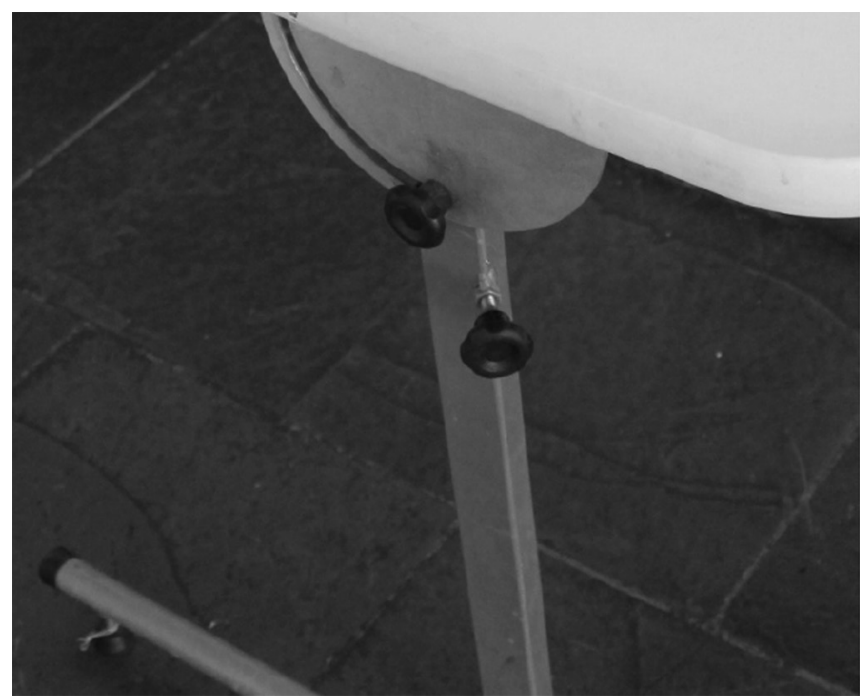

Figure 4. The clamping knobs of the table. Source: elaborated by the authors. 
The two clamping knobs should be unattached, and the degree of the top board inclination should be adjusted according to the activity to be performed. This type of adjustment was done by professionals only for reasons to explain how the mechanism works, because in practice it was explained that this kind of regulation is almost never used: "The regulation is lax, unstable..." It tilts, falls all the time, with everything that is on the tabletop, and on top of the child who is using the table. Some kids have fun with this, finding a certain grace in things sliding down the table, but this is actually a malfunction. Therefore, it is preferable to keep the table without any inclination to maintain some stability in its use, making adaptations to its designed use (e.g. using the inclined plane with a sticky mat over it, to aid children on reading and painting). This unstable setting of the top item was a unanimous complaint among all respondents.

Another aggravating factor is the material that covers the tabletop, made of melamine resin, which is very slippery, and even with little inclination of the tabletop it allows for objects to slide over it. These problems should be seriously considered, given the different contexts of the table's use, such as the use in feeding activities, where there were reports of plates and glasses falling on to children (including some dishes being broken by hitting the floor). Such adverse situations lead to the observation of peculiar operating modes to perform tasks, such as placing a bed sheet on the laps/chests of children with little motor coordination, due to the great possibility of the meal slipping.

In Figure 5, the need for placing the adhesive mat on the carpet surface can be observed, preventing the sliding of the support painting. likewise in Figure 6, the necessity of placing a bed sheet over the child, so he does not become dirty if the table accidentally disarm (a relatively common occurrence) can be observed.

Some statements, such as found in the report from an occupational therapist, clearly reflect the difficulties of using this furniture:

I have 30 minutes sessions of therapy, in which I have to use the table... I spend ten minutes adjusting it, according to the child, if I don't have time to do this before. It's complicated, I lose too much time, it does not optimize my work. When it's possible, I use my own table without clipping and without any adjustment to avoid messing with this adjustable table.

Other impressions of the table were reported, as for example referring to the semi elliptical cut, for better accommodation of the wheelchair user. "This could be a little higher, because the children and teenagers that are slightly larger or overweight do not fit well in such a cut".

According to some comments of the pedagogical monitors and responses from the questionnaire, there are still clear and explicit complaints from some wheelchair users of the table about this specific characteristic. The semi-rigid plastic containment of the tabletop has also suffered criticisms, because this piece is not fully attached to the melamine resin. Thus, there is a small gap between these

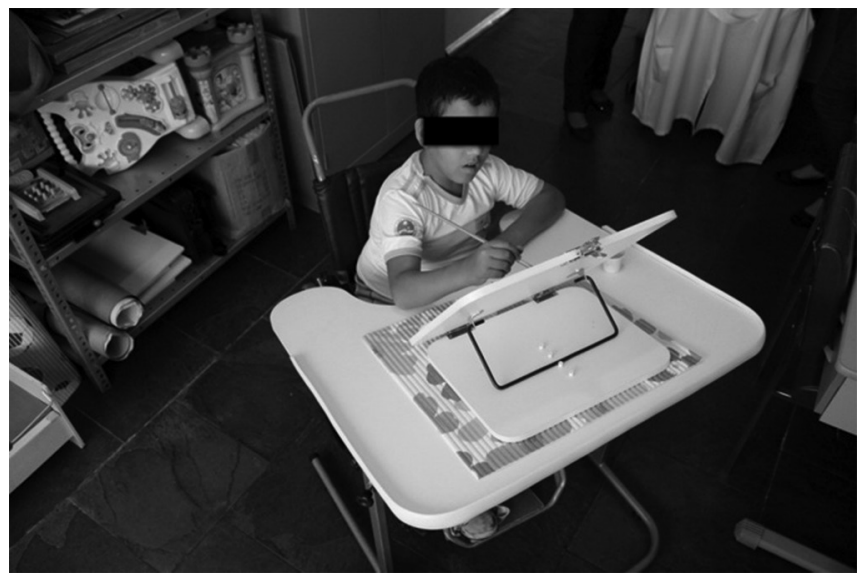

Figure 5. Painting activity, the inclined plane and the sticky carpet. Source: elaborated by the authors.

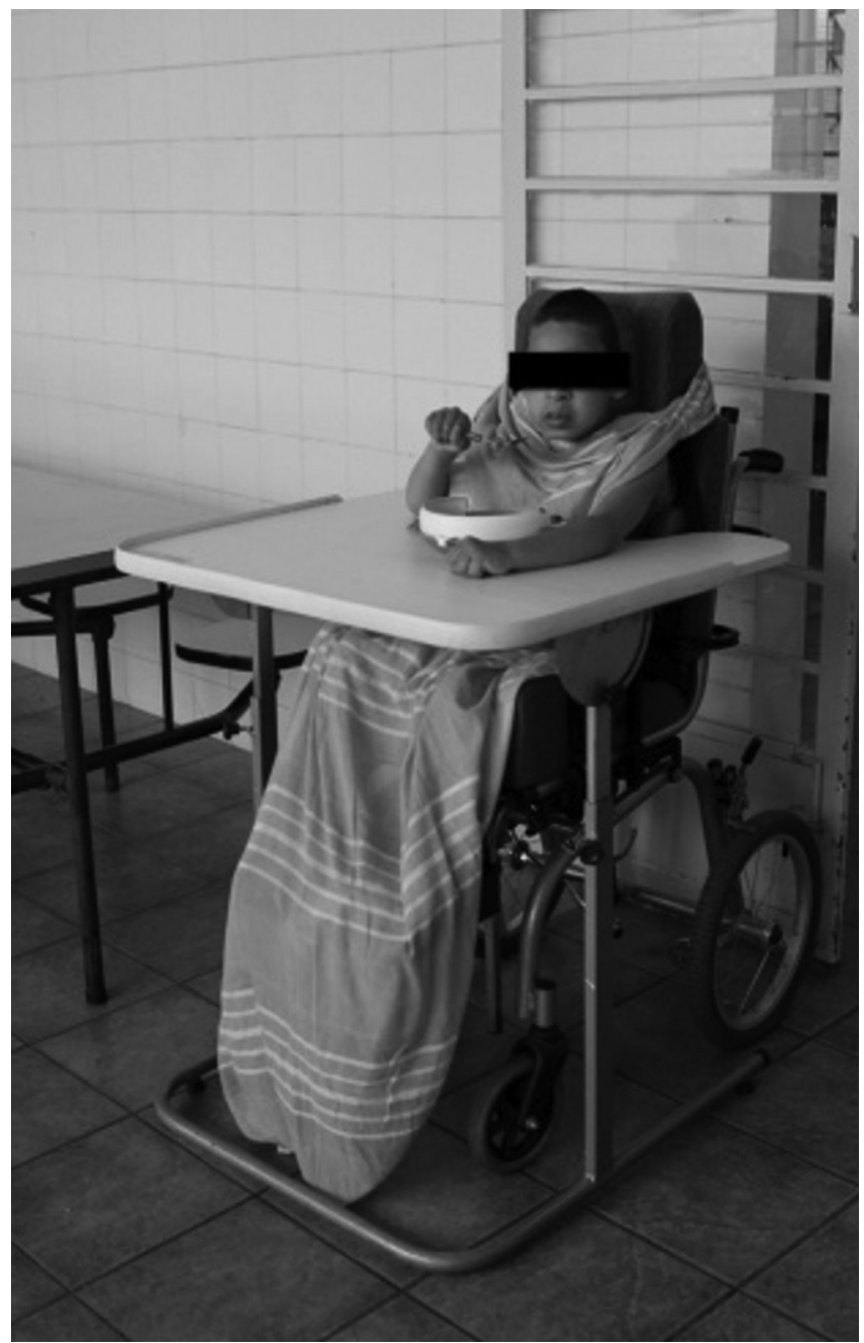

Figure 6. Lunch time (feeding activity). Source: elaborated by the authors. 
two components (approximately 0,19 inches), which serves as an accumulation site for dust and other debris collected from the activities carried out on the table being inaccessible to cleaning. The weight of the table, approximately $22 \mathrm{lbs}$, also consists in a factor that complicates its portability.

The rehabilitation space does not have many tables available - a total of ten tables are owned by the institution, one of which is out of service, waiting for repair. Then, sometimes it is necessary to move this product between the rooms of the institution, and this movement is difficult due to its heavy weight and due to the fact that the table does not fold on its structure - its feet are not retractable or foldable - furthermore resulting in a lack of portability. The suggestion of using casters on the feet to facilitate this procedure was a point emphasized by the interviewees.

The aesthetics of the table was also a question point in the questionnaire, such as in the spontaneous emergence inside of the discourses. The practitioners reported that, especially in an environment of predominantly infantile audience, a model like this could have the option of having a more playful aspect (e.g. use of colors and attractive design), or even have a less mechanical and medical appearance, due to its predominance of metallic and beige tones. Such features would collaborate with the creation of a more light-hearted and fun atmosphere, causing greater product identification with a childhood environment, making the activities more enjoyable.

And so, assumptions and hypotheses about the development process of the product were developed during the conversations and interviews. Some problems encountered on the use of the table made for questions about whether there was any real interaction with the final user of the furniture during this development (such as an adoption of some kind of participatory project or use of collaborative design techniques) because the inadequacies cited above are basic (e.g. items falling from the tabletop causing minor accidents).

All participants showed themselves to be in favor of participating in some product development processes in this area in order to minimize the margin of error that the product could present, giving assurance of more satisfying use for a wheelchair user and his companion. From the entire panorama exposed above, a panel was constructed containing proposals for solutions to the problems encountered in the usage of the adjustable table (see Table 2). The panel was made based on the reports of problems, observations about the table and from the testimonials from professionals and users who live daily with the product.

A new table design was suggested based on the proposed changes, aiming towards better ergonomic suitability as a

Table 2. Categories of analysis, identification of problems and suggested solutions for it.

\begin{tabular}{|c|c|c|}
\hline $\begin{array}{c}\text { Categories of } \\
\text { analysis }\end{array}$ & Identification of problems & Suggested solutions \\
\hline \multirow[t]{2}{*}{ Leveling } & $\begin{array}{l}\text { Difficulty in adjusting the adjustable } \\
\text { rubberized supports. }\end{array}$ & $\begin{array}{l}\text { - Elimination of this regulation: placement of fixed feet; } \\
\text { - Marking the feet to identify the correct height to be regulated; } \\
\text { - System of visible adjusts for this adjustment. }\end{array}$ \\
\hline & $\begin{array}{l}\text { Difficulties to level the table (bilateral } \\
\text { adjustment). }\end{array}$ & - Fixed toothed fittings. \\
\hline $\begin{array}{l}\text { Stability of } \\
\text { structure }\end{array}$ & $\begin{array}{l}\text { Table instability, making it difficult to support } \\
\text { weight, and facilitating the registration of } \\
\text { accessories. }\end{array}$ & $\begin{array}{l}\text { - Fittings toothed fixed; } \\
\text { - Support for the top of the "French hand" type; } \\
\text { - More robust legs. }\end{array}$ \\
\hline $\begin{array}{l}\text { Tabletop } \\
\text { finishing }\end{array}$ & $\begin{array}{l}\text { The top melamine coating allows slippage of } \\
\text { accessories placed on the table. }\end{array}$ & $\begin{array}{l}\text { - Use of more adherent coating on the Formica or placing a lower } \\
\text { contention on the table. }\end{array}$ \\
\hline \multirow{2}{*}{$\begin{array}{l}\text { Tabletop } \\
\text { morphology }\end{array}$} & $\begin{array}{l}\text { The cut of the top is inadequate for some } \\
\text { users. }\end{array}$ & $\begin{array}{l}\text { - Various options of clippings; } \\
\text { - Interchangeable tabletop. }\end{array}$ \\
\hline & $\begin{array}{l}\text { The size of the top causes a considerable } \\
\text { distance between wheelchair user and the } \\
\text { professional (in case of some activities). }\end{array}$ & $\begin{array}{l}\text { - Smaller surface; } \\
\text { - Presence of clipping in both sides, so the companion/professional can } \\
\text { stand in front of the wheelchair user. }\end{array}$ \\
\hline Aesthetics & $\begin{array}{l}\text { The object does not provide a good visual } \\
\text { perception }\end{array}$ & $\begin{array}{l}\text { - Various color options; } \\
\text { - Possibility of customizing (coloring material, or paste figures); } \\
\text { - Minimize use of metallic material; } \\
\text { - Keep the visibility of the adjustments mechanisms, but not highlighted. }\end{array}$ \\
\hline Portability & Difficulty to carry the table. & $\begin{array}{l}\text { - Use of retractable feet; } \\
\text { - Use of lighter material; } \\
\text { - Placement of casters with locks; } \\
\text { - Use of recycled plastics as raw materials (or composites, such as wood- } \\
\text { plastic composites). }\end{array}$ \\
\hline
\end{tabular}

Source: elaborated by the authors. 
whole, thinking about a design that would be nicer for the user, and convenient to use in various types of environment. According to the proposal of a participatory project, this model design would pass to groups for assessments (besides other types of dynamics related to the product) with the intent of suiting the preliminary characteristics of this new furniture on the experiences and sensations of future users (e.g. refinement of the type of material, shape, dimensions, etc), generating a functional prototype for testing purposes - tending towards the evolution and validation of this collaboration, towards the final prototype.

Figures 7, 8, 9 and 10 show the drawings with suggestions for this new table model and its adjustment mechanisms. The feet of this model are made by a two-plate sandwich, constituted by a tetrapack recycled material (this material is the basis of all the external structures of the table). Styrofoam is a high density foam present inside this leg, structuring the internal components of height adjustment present on the table.

Three pieces are attached to this leg, a steel central disk (internally, used for the regulation of the angle), a metal clamp (externally, it is a quick release lever, commonly used
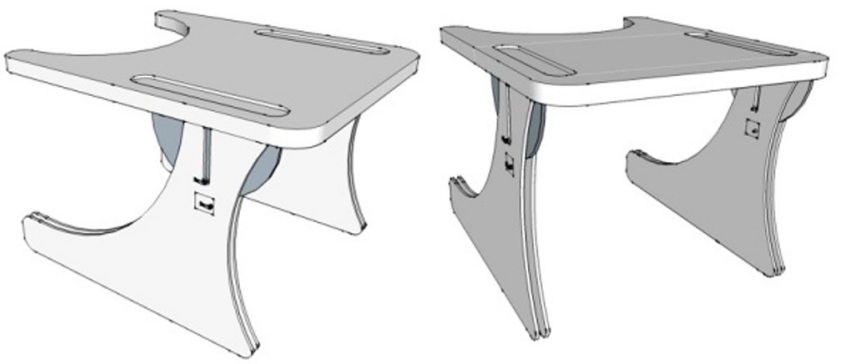

Figure 7. The new concept of table. Source: elaborated by the authors.
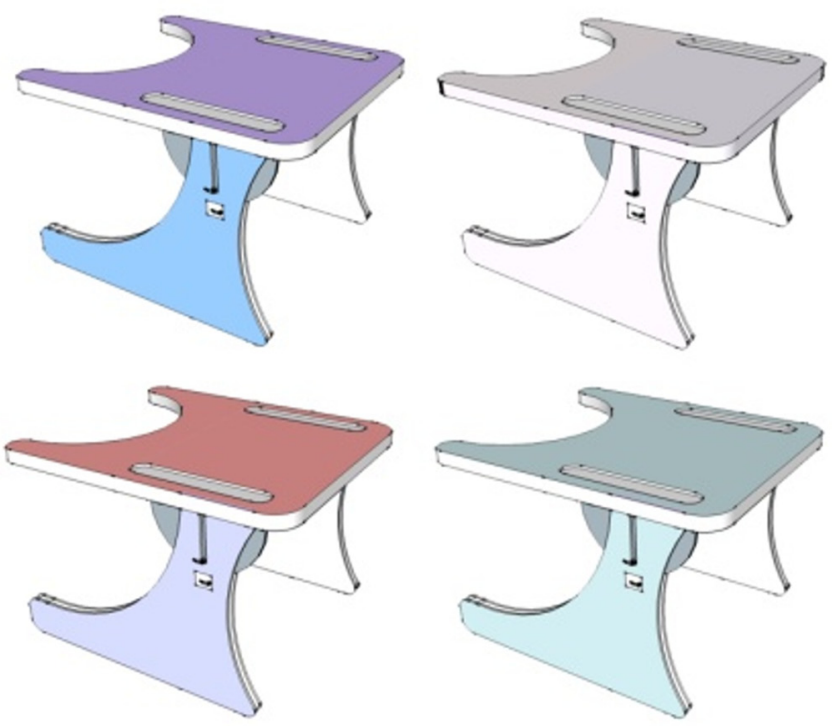

Figure 8. Colored tables. Source: elaborated by the authors. on bicycle seats) and a rectangular steel tube (internally). These adjusts made with the clamp will guide the height (marked with signs) and the articulation of the table top, easily performed by one person. This project uses low-cost materials, suggesting a final low price to consumer.

\section{Conclusion}

Therefore, it was noted that the use of a table adapted for wheelchair users is essential in many environments, such as found in the analyzed institution, in which there are rehabilitation, recreation and learning activities aimed at adolescents and children with multiple kinds of disabilities.

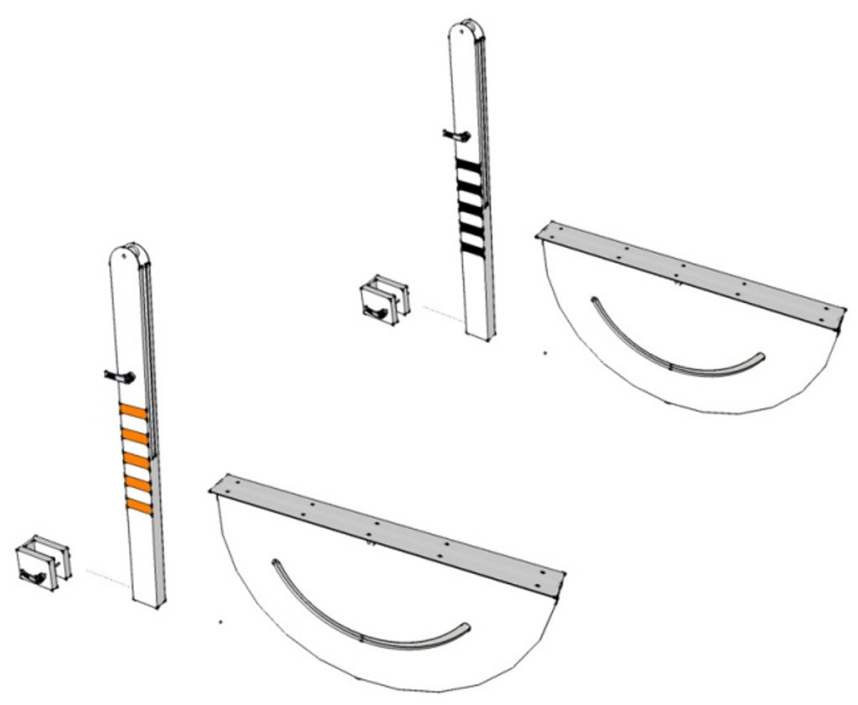

Figure 9. Schematic internal pieces of the table. Source: elaborated by the authors.

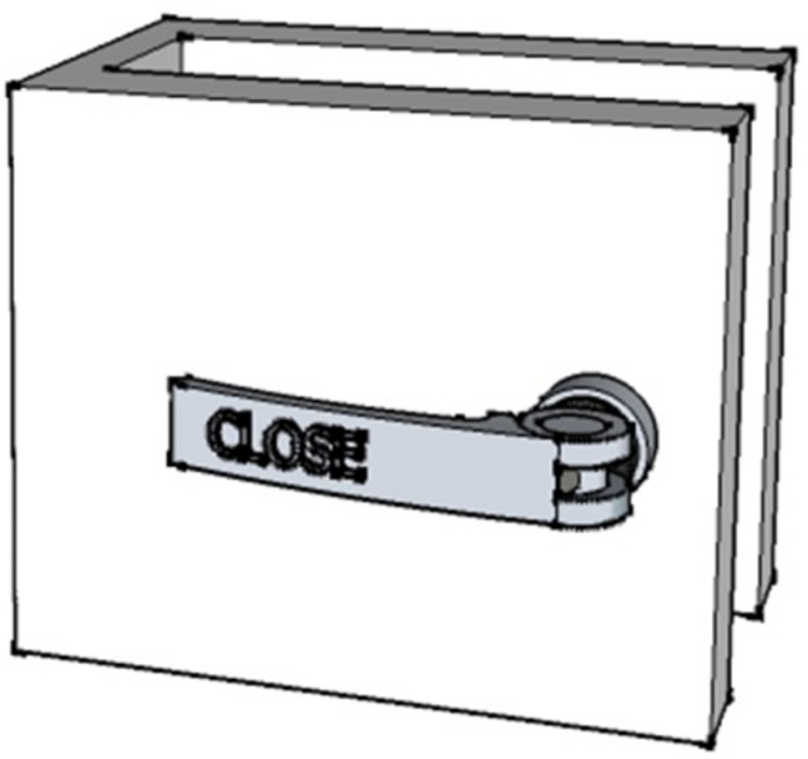

Figure 10. Detail of the clamp, commonly used in bicycles. Source: elaborated by the authors. 
Of equal importance is the existence of adjustable furniture in spaces where the wheelchair users (of any age), have to perform tasks with the aid of a table, such as in a workplace or for other activities in the home, providing ergonomic suitability and satisfaction in performing any task whatsoever.

For this, various features in the project showed up to be essential, for example the aspects relating to good usability, denoting clarity and ease, and providing high efficiency in its use without also excluding subjective aspects in its constitution, allowing the product to be usable in many contexts, without stigma.

The reported dissatisfaction in use form the questionnaires are linked on the inadequacy of the table's features of covering the needs demanded by the users. This inadequacy may be related to the particular use for which the institution is using the product, that may be different from those designed by the manufacturer, or by the lack of user interaction in the development of projects. The first option unfortunately occurs due to pricing, ease of purchase or due to the buyer's ignorance. The second, caused by the lack of interaction with potential users of the product during its development process could be a way to help answering such diverse open questions left to the user, creating room for leeway and understanding dissatisfaction.

Professionals, relatives, and obviously, the wheelchair users themselves, have the expertise about the possibilities of exploitation and use, possessing the potential to collaborate with designers and developers through participatory methodologies, for the realization of an optimized and unique design project (in case of a product redesign), considering that little furniture on the Brazilian market offers the opportunity of so much flexibility to its users, as this analyzed model offers.

As the directions and suggestions proposed by this study are used for a more participatory methodology on product development projects, increasing, spreading and practicing activities of stimulating the user interaction with products that will be launched at market, and also, improvements in post-purchase programs with user relationships, with the intention of collecting data about user satisfaction through opinions and feedbacks, to be used in project improvements.

\section{References}

ABLEDATA. Abledata. 2015. Available from: $<\mathrm{http}: / / \mathrm{www}$. abledata.com>. Access in: 25 Jan 2015.

ASSOCIAÇÃO BRASILEIRA DE NORMAS TÉCNICAS - ABNT. NBR 9050/2004: acessibilidade a edificações, mobiliário, espaços e equipamentos urbanos. Rio de Janeiro, 2004. 97 p.

ASSOCIAÇÃO BRASILEIRA DE NORMAS TÉCNICAS ABNT. NBR 13966/2008: móveis para escritório. Mesas: classificação e características físicas dimensionais e requisitos e métodos de ensaio. Rio de Janeiro, 2008. 19 p.
BARTALOTTI, C. C. Inclusão social das pessoas com deficiência: utopia ou possibilidade? 1st ed. São Paulo: Paulus, 2006. 60 p.

BENEDETTO, I. L. C. Contribuições metodológicas para o desenvolvimento de produtos em tecnologia assistiva. 2011. 162 p. Thesis (Doctoral in Design)-Escola de Engenharia, Universidade Federal do Rio Grande do Sul, Porto Alegre, 2011.

BISPO, R.; BRANCO, V. Designing out stigma: the role of objects in the construction of disabled people's identity. In: DARE TO DESIRE: INT'L DESIGN \& EMOTION CONFERENCE, 6., 2008, Hong Kong. Proceedings... Leiria: Instituto Politécnico de Leiria, 2008. 5 p.

BRASIL. Ministério da Ciência Tecnologia e Inovação. Catálogo nacional de produtos de tecnologia assistiva. Brasília: MCTI/SECIS, 2013. Available from: <http:// assistiva.mct.gov.br/catalogo/fabricantes $>$. Access in: 21 Nov 2014.

BROOKE, J. SUS: a quick and dirty usability scale. In: JORDAN, P. W. et al. (Ed.). Usability evaluation. London: Taylor \& Francis, 1996. p. 189-194.

COOK, A. M.; HUSSEY, S. M. Assistive technologies: principles and practice. 2nd ed. St. Louis: Mosby, 2002.

CRESWELL, J. W. Research design: qualitative, quantitative, and mixed method approaches. 2nd ed. California: Sage, 2003. $26 \mathrm{p}$.

DEJOURS, C. Subjetividade, trabalho e ação. Production, v. 14, n. 3, p. 27-034, 2004.

DESMET, P. M. A.; DIJKHUIS, E. A wheelchair can be fun: a case of emotion-driven design. In: INTERNATIONAL CONFERENCE ON DESIGNING PLEASURABLE PRODUCTS AND INTERFACES, 3., 2003, Pittsburg. Proceedings... New York: ACM, 2003. p. 22-27.

FOLEY, J. D. et al. Computer graphics: principles and practice. 2nd ed. London: Addison-Wesley, 1997. 1175 p.

GAITHER, N.; FRAZIER, G. Administração da produção e operações. 8nd ed. São Paulo: Pioneira Thomson Learning, 2002. $598 \mathrm{p}$.

GALVÃO FILHO, T. A.; GARCIA, J. C. D. Pesquisa nacional de tecnologia assistiva. São Paulo: Insituto de Tecnologia Social do Brasil, 2012. Available from: <http://www. itsbrasil.org.br/sites/itsbrasil.w20.com.br/files/Digite\%20 o\%20texto/miolopesqnacional-grafica.pdf $>$. Access in: 30 Nov 2014.

GIL, A. C. Como elaborar projetos de pesquisa. 4th ed. São Paulo: Atlas, 2002. 175 p.

INSTITUTO BRASILEIRO DE GEOGRAFIA E ESTATÍSTICA - IBGE. Censo demográfico 2010: resultados gerais da amostra. Rio de Janeiro: IBGE, 2012. 
Available from: < http://www.ibge.gov.br/home/presidencia/ noticias/imprensa/ppts/0000000847310412201231572748 3985.pdf>. Access in: 29 Nov 2014.

INTERNATIONAL ERGONOMICS ASSOCIATION - IEA. Ergonomics. 2014. Available from: <http://www.iea.cc $>$. Access in: 25 Nov 2014.

JORDAN, P. W. An introduction to usability. 1st ed. London: Taylor \& Francis, 1998. 136 p.

KARWOSKI, W. IEA facts and background. Louisvilee: IEA Press, 1996. 43 p.

KULPA, C. C. et al. Um modelo de cores na usabilidade das interfaces computacionais para os deficientes de baixa visão. Design \& Tecnologia, v. 1, p. 66-78, 2010.

LANUTTI, J. N. L. P. et al. Usabilidade de objetos de uso cotidiano comparativo de técnicas de avaliação subjetiva (SUS e DS). In: CONGRESSO INTERNACIONAL DE ERGONOMIA E USABILIDADE DE INTERFACES HUMANO-TECNOLOGIA: PRODUTO, INFORMAÇÕES, AMBIENTE CONSTRUÍDO E TRANSPORTE, 13., 2013, Juiz de Fora. Anais... Juiz de Fora: ERGODESIGN/UFJF, 2013. 11 p.

MAFRA, S. R. C. O Lúdico e o desenvolvimento da criança deficiente intelectual. São Paulo: Secretaria de Estado da Educação, 2008. Available from: <http://www. diaadiaeducacao.pr.gov.br/portals/pde/arquivos/2444-6. pdf>. Access in: 22 Nov 2014.

MANN, W. C. Effectiveness of assistive technology and environmental interventions in maintaining independence and reducing home care costs for the frail elderly: a randomized controlled trial. Archives of Family Medicine, v. 8, n. 3, p. 210-217, 1999. http://dx.doi.org/10.1001/ archfami.8.3.210. PMid:10333815.

MARCUS, A. Color: a tool for computer graphics communication. In: GREENBERG, D. et al. Color in computer graphics. Boston: Addison-Wesley, 1982. p. 76-90.

NEWELL, A. F.; GREGOR, P. User sensitive inclusive design: in search of a new paradigm. In: SCHOLTZ, J.; THOMAS, J. (Eds.). CUU: ACM CONFERENCE ON UNIVERSAL USABILITY, 1., 2000, Arlington. Proceedings... New York: ACM Press, 2000. p. 39-44.
NIELSEN, J. Usability engineering. 1st ed. Massachusetts: Morgan Kaufman, 1993. 362 p.

NORMAN, D. The design of everyday things. New York: Basic Books, 1986. 368 p.

NORMAN, D. Design emocional: por que adoramos (ou detestamos) os objetos do dia a dia. 1st ed. Rio de Janeiro: Rocco, 2008. 322 p.

PALACIOS, A. EI modelo social de discapacidad: orígenes, caracterización y plasmación en la Convención Internacional sobre los Derechos de las Personas com Discapacidad. 1st ed. Madrid: Cinca, 2008. 524 p.

PHEASANT, S. Bodyspace: anthropometry, ergonomics and the design of work. London: Taylor \& Francis, 1997. 244 p.

PHILLIPS, B.; ZHAO, H. Predictors of assistive technology abandonment. Assistive Technology, v. 5, n. 1, p. 36-45, 1993. http://dx.doi.org/10.1080/10400435.1993.10132205 . PMid:10171664.

PULLIN, G. Design meets disability. 1st ed. Cambridge: The MIT Press, 2009. 268 p.

SANTOS, D. C. O. Potenciais dificuldades e facilidades na educação de alunos com deficiência intelectual. Educação e Pesquisa, v. 38, n. 4, p. 935-948, 2012. http://dx.doi. org/10.1590/S1517-97022012000400010.

SAWAIA, B. B. Introdução: exclusão ou inclusão perversa? In: SAWAIA, B. B. (Org.). As artimanhas da exclusão: análise psicossocial e ética da desigualdade social. São Paulo: Vozes, 1999. p. 07-13.

STAKE, R. The art of case study research. Thousand Oaks: Sage, 1995. $192 \mathrm{p}$.

VON HIPPEL, E. Democratizing innovation. Cambridge: The MIT Press, 2005. 204 p.

VYGOTSKI, L. S. A formação social da mente. 4th ed. São Paulo: Martins Fontes, 1991. 90 p.

WESSELS, R. et al. Non-use of provided assistive technology devices, a literature overview. Technology \& Disability, v. 15, n. 4, p. 231-238, 2003.

WORLD HEALTH ORGANIZATION - WHO. World report on disability. Geneva, 2011. 350 p. Available from: $<$ http:// whqlibdoc.who.int/publications/2011/9789240685215_eng. pdf?ua=1>. Access in: 26 Nov 2014. 